\title{
SOSIALISASI PENTINGNYA KETERAMPILAN SOSIAL GURU DALAM KEGIATAN PEMBELAJARAN UNTUK MENCEGAH KECEMASAN SISWA BERSEKOLAH
}

\author{
Darmiany'), I Nyoman Karma1), I Ketut Widiada1), Iva Nurmawanti'1), \\ Setiani Novitasari1) \\ 1)Pendidikan Guru Sekolah Dasar, Fakultas Keguruan dan IImu Penddidikan, Universitas Mataram, Mataram, NTB, \\ Indonesia \\ Corresponding author : Iva Nurmawanti \\ E-mail : ivanurmawanti@unram.ac.id
}

Diterima 22 November 2021, Direvisi 04 April 2021, Disetujui 04 April 2021

\begin{abstract}
ABSTRAK
Kecemasan bersekolah merupakan masalah yang masih dialami oleh siswa di Sekolah Dasar. Masalah ini harus dicegah karena jika dialami oleh siswa dapat mempengaruhi prestasi akademik siswa di sekolah. Proses pembelajaran yang kurang tepat dilakukan oleh guru dapat mempengaruhi munculnya masalah kecemasan bersekolah siswa. Oleh sebab itu diperlukan keterampilan sosial yang baik dari guru dalam melakukan proses pembelajaran. Berdasarkan hal tersebut, tujuan dari pengabdian ini untuk memberikan pemahaman terkait pentingnya keterampilan sosial guru dalam melakukan proses pembelajaran sesuai dengan masalah yang terjadi yaitu dapat mengurangi kecemasan bersekolah siswa. Metode yang digunakan meliputi tiga tahapan yaitu persiapan, pelaksanaan, dan evaluasi. Berdasarkan hasil dari kegiatan ini peserta sangat antusias dalam mengikuti kegiatan dan berdasarkan angket terbuka sebagai bahan evaluasi yang diberikan diperoleh hasil bahwa semua memahami materi dan dapat merefleksikan terkait pentingnya keterampilan mereka dengan pengalaman yang telah mereka lakukan..
\end{abstract}

Kata kunci: sosialisasi; keterampilan sosial; kecemasan bersekolah.

\begin{abstract}
School anxiety is a problem that is still experienced by students in elementary schools. This problem must be prevented because if it is experienced by students it can affect students' academic achievement in school. The learning process that is not properly carried out by the teacher can affect the emergence of students' school anxiety problems. Therefore, good sosial skills are needed from the teacher in carrying out the learning process. Based on this, the purpose of this service is to provide an understanding of the importance of teachers' social skills in carrying out the learning process in accordance with the problems that occur, namely to reduce the school anxiety. The method in this service are preparation, implementation, and evaluation are the methods in this service. Based on the results of this activity the participants were very enthusiastic in participating in the activity and based on an open questionnaire as an evaluation material provided, it was found that all understood the material and could reflect on the importance of their skills with the experiences they had done.
\end{abstract}

Keywords: sosialization; teacher sosial skills; school anxiety.

\section{PENDAHULUAN}

Kecemasan dapat diartikan ketidaknyamanan perasaan, yang tampak pada munculnya respon psikofisik untuk mengantisipasi bahaya yang dibanyangkan akan terjadi (Jannah, 2017). Kecemasan bersekolah merupakan salah satu masalah akademik dalam mengoptimalkan prestasi belajar siswa. Apabila siswa merasakan kecemasan terhadap objek-objek yang berhubungan dengan persekolahan, ia tidak bisa hadir secara total untuk mengikuti pelajaran di kelas.
Pada proses belajar-mengajar siswa hendaknya terlibat secara total baik fisikal maupun intelektual. Keterlibatan siswa dalam kegiatan pembelajaran secara fisikal bersifat administratif dan nyata. Namun, secara intelektual baik yang bersifat kognitif dalam arti pemahaman maupun afektif dalam arti siswa menyadari pentingnya memahami pelajaran itu adalah samar dan hanya dapat diketahui melalui evaluasi. Keterlibatan siswa dalam pembelajaran yang diimbangi dengan control emosi, domain afektif dan kognitif yang baik dapat meningkatkan prestasi akademiknya (Sa 
\& Ariati, 2018). Namun jika keterlibatan siswa kurang juga akan berlaku sebaliknya. Salah satunya reaksi afektif negatif dari siswa akan tampak bahwa siswa mengalami kebosanan, kecemasan, kemalasan, sehingga ada kecenderungan untuk tidak mau mengerjakan tugas akademik, enggan sekolah, dan bisa kemungkinan mau berhenti sekolah (Vivin, 2019).

Keterlibatan siswa secara total tercipta bila iklim kelas yang baik dapat diterjadikan oleh guru melalui pengelolaan kelas, disiplin kelas, dan penyajian materi pelajaran dalam kegiatan pembelajaran. Perilaku guru dalam kegiatan pembelajaran yang gagal menciptakan tata krama kelas yang humanis dan harmonis, membuat siswa-siswa takut yang selanjutnya dapat menyebabkan kecemasan dalam berbagai hal yang berhubungan dengan sekolah. Tatakrama yang humanis dan harmonis di dalam kegiatan pembelajaran diperlukan untuk menciptakan iklim kelas yang menunjang terfasilitasinya transfer pembelajaran secara efektif. Interaksi antara guru dan siswa yang harmonis dan efektif melalui pendekatan psikologis, pedagogis, dan sosiologis sangat diperlukan dalam kegiatan pembelajaran dan dapat meningkatkan motivasi belajar siswa (Sudiarta, 2016).

Berdasarkan studi pendahuluan yang dilakukan di sejumlah SD di wilayah NTB khususnya di kota Mataram, menunjukkan bahwa sebagian besar guru SD mengalami kesulitan menghadapi ke unikan masalah dan perkembangan peserta didik. Dalam pengamatan ditemukan bahwa dalam pembelajaran di kelas guru seringkali mengambil keputusan dan bertindak secara emosional, sehingga menimbulkan persepsi dan kesan buruk kepada peserta didik. Dampak dari kegagalan guru dalam menciptakan tatakrama yang baik tidak hanya berdampak pada kegagalan mencapai tujuan instruksional pembelajaran yang diacarakan, tetapi lebih jauh telah merusak mental siswa untuk bersekolah (Raka, 1984). Bahkan beberapa diantara siswa mungkin akan mengalami gangguan kecemasan bersekolah.

Berdasarkan masalah tersebut, solusi yang ditawarkan adalah guru harus memiliki keterampilan sosial. Keterampilan sosial guru merupakan suatu kompetensi fundamental yang harus dimiliki guru (Tynjälä, et.al 2016). Hal ini disebabkan gurulah yang menganalisis dinamika di kelas, menciptakan iklim kelas yang kondusif dapat mendukung kesusksesan pelaksanaan proses pembelajaran, dan menjalin interaksi yang baik dengan siswa dan orang tua. Dalam menciptakan iklim kelas yang kondusif dapat diciptakan melalui keramahan, perhatian, dan bimbingan, yang merupakan unsur keterampilan sosial (Borich, 1994). Interaksi sosial yang baik antara guru dan siswa juga berhubungan dengan keterampilan sosial peserta didik (Wu et al., 2018).

Berdasarkan pemaparan di atas, penting untuk dilaksanakan pengabdian masyarakan untuk mencegah kecemasan bersekolah anak di NTB dan pentingnya sosialisasi keterampilan sosial guru. Adapun sasaran dari kegiatan ini adalah mahasiswa semester 7 PGSD Universitas Mataram. Hal ini disebabkan karena mahasiswa semester 7 akan terjun langsung ke lapangan dalam kegiatan PPL. Selain itu mahasiwa juga diharapkan sebagai penggerak untuk agen sosialisasi tentang pentingnya keterampilan sosial di sekolah-sekolah di NTB.

\section{METODE}

Metode dalam pengabdian masyarakat ini ada tiga tahapan yaitu persiapan, pelaksanaan, dan evaluasi. Adapun tahapantahapan tersebut akan dipaparkan sebagai berikut:

1. Persiapan dilakukan yaitu melakukan studi pendahuluan dengan survey analisis situasi tentang kecemasan bersekolah anak di beberapa sekolah di NTB khususnya di Mataram. Studi Pendahuluan dilakukan dengan melakukan wawancara kepada beberapa guru maupun orang tua. Selanjutnya dilakukan perencanaan kegiatan yang meliputi membuat judul pengabdian, menentukan sasaran, merencanakan jadwal kegiatan, membuat materi, dan menentukan penangjawab dalam pelaksanaan setiap kegiatan.

\section{Pelaksanaan}

Pada tahap pelaksanaan, kegiatan sosialisasi yang semula direncanakan melalui tatap muka langsung, diganti melalui daring. Hal ini disebabkan karena kondisi yang tidak memungkinkan melakukan tatap muka dikarenakan pandemi Covid-19. Adapun pelaksanaan sosialisasi dilaksanakan selama 2 jam melalui aplikasi zoom meeting. Luaran dari kegiatan ini dalam bentuk artikel yang akan diterbitkan selain untuk dimanfaatkan oleh mahasiswa juga dapat dimanfaatkan oleh masyarakat luas.

\section{Evaluasi}

Evaluasi kegiatan dilakukan selain dari pengamatan terhadap pelaksanaan kegiatan juga berdasarkan form refleksi yang diberikan kepada peserta setelah mengikuti kegiatan. Evaluasi kegiatan bertujuan untuk mengukur keberhasilan pelaksanaan kegiatan pengabdian masyarakat ini. Hal ini dapat 
digunakan sebagai perbaikan untuk pelaksanaan kegiatan sejenis yang akan dilakukan di kemudian hari. Adapun laporan hasil evaluasi akan disusun dalam laporan Pengabdian Internal Universitas Mataram.

\section{HASIL DAN PEMBAHASAN \\ Perencanaan Kegiatan}

Kegiatan Pengabdian Masyarakat yaitu "Sosialisasi Pentingnya Keterampilan Sosial Guru Dalam Kegiatan Pembelajaran Untuk Mencegah Kecemasan Siswa Bersekolah" dilaksanakan sesuai dengan apa yang direncanakan. Meskipun ada beberapa hal yang berubah dari perencanaan semula disebabkan karena pandemi Covid-19. Perubahan yang terjadi yaitu teknis pelaksanaan yang semula direncanakan secara tatap muka menjadi dilaksanakan secara daring.

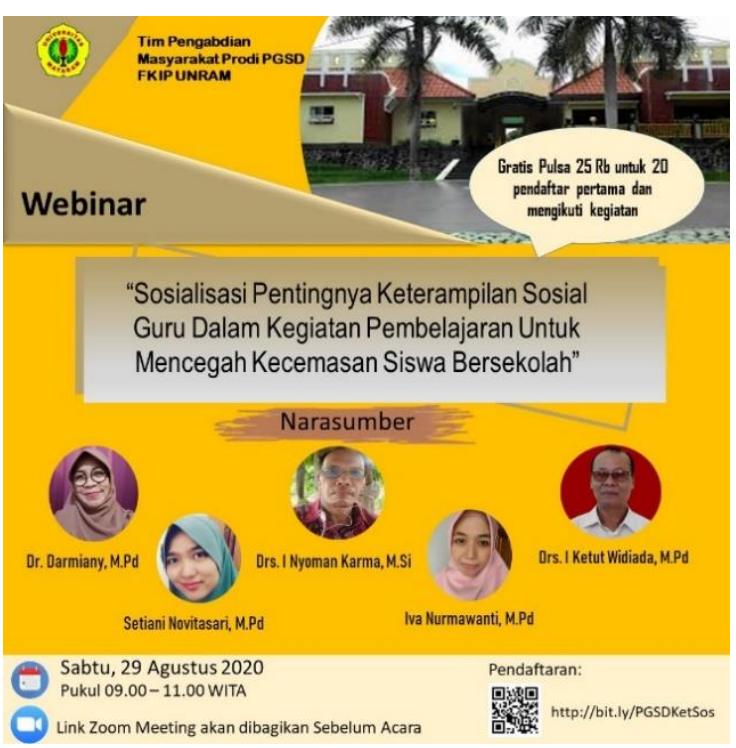

Gambar 1. Flayer Webinar Pengabdian

\section{Pelaksanaan Kegiatan}

Kegiatan sosialisasi dilaksanakan pada hari Sabtu 29 Agustus 2020. Kegiatan ini dilaksanakan selama 2 jam dengan diikuti peserta sebanyak 60 peserta. Pelaksanaan kegiatan ini dilakukan secara daring. Adapun narasumber kegiatan ini yaitu anggota tim pengabdian masyarakat. Penyampain materi dilakukan menggunakan metode pelatihan melalui ceramah dan diskusi tanya jawab.

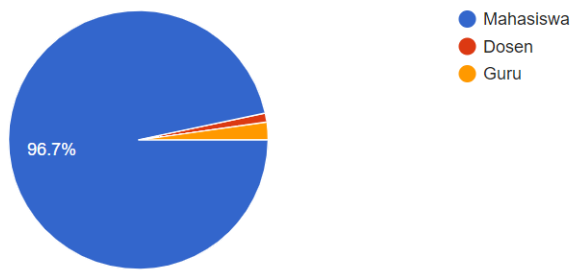

Gambar 2. Peserta pengabdian
Materi yang disampaikan pada kegiatan yaitu tentang: 1) penciptaan hubungan baik antara guru dengan siswa dapat menumbuhkan, membina rasa saling percaya dan saling menghargai dalam interaksi PBM, 2) Interaksi sosial yang dinamis yang memunculkan iklim harapan belajar yang tinggi, 3) menumbuhkan harapan belajar siswa pada guru agar motivasi belajar siswa tinggi, 4) menumbuhkan harapan guru ke siswa yang memicu tingginya antusiasme guru dalam mengoptimalkan hasil pembelajaran.

Pembahasan keterampilan sosial guru dalam kegiatan sosialisasi ini merujuk pada teori "Emotional Intelligence" yang mengkaji aspek-aspek interaksi dari segi kecerdasan emosional (Goleman, 1999). Teori Goleman menekankan masalah-masalah interpersonal yang timbul dalam berbagai ranah kehidupan, yang dalam kaitan ini mencakup mulai dari lingkungan rumah tangga, sekolah, tempat kerja, dan interaksi sosial di tempat lain pada dimensi yang berbeda-beda, tidak terletak pada IQ (Intelligence Quotient) tetapi ada pada "kecerdasan emosional". Tumpulnya kecerdasan emosional pada seseorang menimbulkan ketimpangan dan masalah sosial dalam pergaulan sehari-hari dengan orang 6 lain. Oleh sebab itu, kecerdasan emosional dianggap berperan penting dalam mendampingi kecerdasan koginitif, bahkan pada keadaan-keadaan tertentu dalam melakukam interaksi, emosi mestinya mengawal kognisi (Goleman, 1999).

Ulasan Goleman tentang pentingnya kecerdasan emosional dalam berbagai situasi genting menghadapi orang lain sangat dibutuhkan untuk mencapai sukses, termasuk dalam sesi-sesi pembelajaran di kelas. Kecerdasan emosional dalam hal kemampuan interpersonal adalah menyangkut "sosial arts", yaitu kemampuan seseorang untuk memahami dan mengendalikan perasaannya sendiri, memahami dan memaknai secara tepat emosi orang lain, menanggapi dan merespon dengan bijak keinginan orang lain secara konstruktif, serta memelihara hubungan interaksi secara bermakna dan harmonis adalah sebuah "seni dalam pergaulan".

Mengantisipasi gejala kecenderungan kecemasan bagi peserta didik, para ahli dalam Manajemen Kelas (Classroom Management) berpendapat bahwa cara terbaik untuk mengelola kelas adalah selain guru memiliki dan menerapkan keterampilan sosial, guru harus bertanya kepada diri sendiri tentang pengelolaan ruang fisik kelas yang bagaimana yang paling tepat untuk kelasnya, yang memungkinkan pengelolaan peserta didik dan waktu belajarnya dapat dilakukan dengan baik. 
Selanjutnya, guru dapat menawarkan, menyepakati aturan-aturan kelas bersamasama dengan peserta didik, dan mengkomunikasikannya kepada peserta didik untuk memastikan kedisiplinan kelas tetap terjaga tanpa mengesankan adanya pembatasan akademik bagi siswa. Kemudian, guru dapat menyajikan materi pelajarannya melalui rencana pembelajaran, prosedur pelaksanaan, dan teknik pengevaluasian yang baik. Apabila pengelolaan ruang fisik kelas, disiplin kelas, dan penyajian materi pembelajaran dapat diakselerasikan dengan Model-model Pembelajaran yang dikemukakan oleh Joyce \& Weil (1980), maka formulasi iklim pembelajaran yang baik untuk memfasilitasi kegiatan pembelajaran di kelas dapat ditemukan dan diterapkan dengan pas sesuai kebutuhan peserta didik.

Unsur-unsur penting yang harus diperhatikan Guru terkait keterampilan sosial dalam

PBM adalah sebagai berikut:

a) Kesadaran emosi diri merupakan simpul potensi emosional yang mengandung kemampuan memonitor perasaan diri sendiri yang muncul sebagai respon terhadap objek tertentu. Kesadaran emosi diri ini dapat juga berupa kemampuan untuk mengenali kekuatan sekaligus kelemahan diri sendiri, serta melihat diri sendiri dalam sisi-sisi yang realistik.

b) Pengelolaan emosi adalah kemampuan menguasai dan mengontrol diri dari irama emosi yang berfluktuasi sebagai respons terhadap berbagai hal yang terjadi di sekitarnya. Pengelolaan emosi bermanfaat untuk mengidentifikasi dan mengenali diri secara kontekstual.

c) Pemanfaatan emosi secara produktif merupakan kemampuan spesifik yang dimiliki seseorang, yang dapat dikerahkan dalam memotivasi diri dan membangun optimisme. Emosi dalam hal ini merupakan potensi yang dapat dimanfaatkan dalam proses mencapai tujuan dengan cara dan hasil yang lebih baik.

d) Rasa empati sebagai kemampuan untuk memahami orang lain dalam konteks interaksi, merupakan sebuah kepekaan untuk ikut merasakan perasaan orang lain dari perspektif objek. Rasa empati dapat mengajarkan seseorang untuk memahami perasaan dan penghargaan terhadap orang lain. Pemahaman itu dapat meliputi berbagai macam hal yang dialami oleh orang lain dan hal itu dapat membangun keakraban hubungan dengan orang lain.

e) Membina hubungan dengan orang lain merupakan kemampuan untuk bekerjasama dalam mewujudkan kepentingan yang hanya bisa diperoleh melalui interaksi secara relasional dengan pihak lain.

Para peserta sangat antusias dalam mengikuti kegiatan sosialisasi ini. Hal ini dibuktikan dari keikutsertaan peserta mulai dari awal sampai akhir tercatat hanya ada dua peserta yang meninggalkan kegiatan. Pada awal kegiatan ada 60 peserta dan di akhir kegiatan ada 58 peserta. Pada sesi penyampaian materi antusias peserta juga terlihat dari keaktifan peserta memberikan pertanyaan pada kolom chat setelah materi disampaikan pada masing-masing sesi materi.

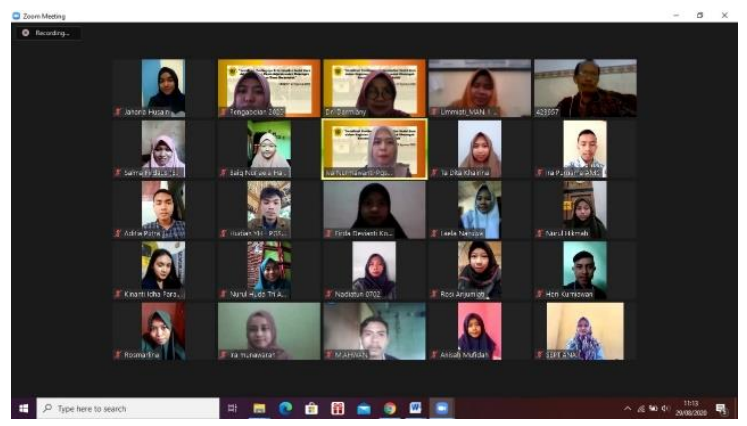

Gambar 3. Kegiatan Webinar Pengabdian

Pada sesi diskusi, beberapa pertanyaan dari peserta sangat menarik pertanyaan-pertanyaan tersebut diantaranya:

a) Bagaimana tips yang ibu bisa berikan kepada kami calon pendidik untuk mengelola Emosional Negatif saat kita mengajar bu?? Supaya proses pembelajaran berlangsung dengan baik.

b) Bagaimana cara kita sebagai calon guru mendapatkan kepercayaan peserta didik, supaya peserta didik mau menceritakan masalah yang membuat dia tidak fokus dalam belajar?

c) Berdasarkan dari pemaran pemateri, menurut saya saat ini Guru SD khususnya di tuntut untuk menjadi Pendidik yang professional. Selain materi pelajaran yang harus kami kuasai, kami dituntut juga untuk mampu menyelesaikan masalah psikologis peserta didik. Menurut saya atas dasar ini tuntutan guru kelas di SD sangat banyak. Mengapa di SD tidak ada guru khusus yang menangani konsling ataupun kepribadian anak seperti di SMP dan SMA?

\section{Evaluasi Kegiatan}

Berdasarkan angket yang diberikan kepada mahasiswa dapat diketahui bahwa mahasiswa mampu memahami pentingnya keterampilan sosial. Secara khusus keterampilan sosial guru dalam proses belajar untuk mengurangi kecemasan bersekolah. Mahasiswa mampu merefleksikan konsep 
keterampilan sosial dengan pengalaman yang pernah dialami mereka dan dialami orang lain yang mereka ketahui. Sehingga pemahaman mereka terkait pentingnya keterampilan sosial ini jelas terlihar pemaparan mereka terkait hasil refleksi.

Berdasarkan teknis pelaksanaan kegiatan ada beberapa hal yang perlu dievaluasi yaitu berkaitan dengan waktu pelaksanaan kegiatan. Waktu yang dijadwalkan lebih 30 menit dari yang direncanakan. Hal ini disebabkan mahasiswa sanagt antusias dengan menanyakan hal-hal terkait permasalahan yang sering dilakukan guru berkaitan dengan keterampilan sosial. Masalah jaringan juga sedikit menghambat jalannya kegiatan karena jaringan host tiba-tiba hilang. Namun hal ini bisa diatasi dengan jaringan cohost yang stabil.

\section{SIMPULAN}

Kegiatan Sosialisasi ini bertujuan untuk memberikan pemahaman terkait pentingnya keterampilan sosial dalam proses pembelajaran. Khususnya dalam mencegah kecemasan bersekolah. Pelaksanaan pengabdian ini dilaksanakan dalam bentuk webinar. Hal ini disebabkan karena keterbatasan karena pandemi Covid-19. Kegiatan ini diikuti oleh 60 peserta yang terdiri dari guru, dosen, maupun mahasiswa. Mahasiswa yang mengikuti sebagian besar adalah mahasiswa semester 7 Prodi PGSD Universitas Mataram. Setelah mengikuti kegiatan ini mahasiswa diharapkan mampu menjadi penggerak dalam mensosialisasikan pentingnya dan menerapkan keterampilan sosial di sekolah-sekolah di NTB khususnya. Mereka bisa melaksanakan hal tersebut dalam melaksanakan Program PLP (Program Pengenalan Persekolahan) di sekolah. Kegiatan yang dilaksnakan berjalan lancar dan peserta dangat antusias dalam mengikuti kegiatan sampai akhir. Berdasarkan angket yang diberikan peserta juga mampu memahami materi dan mengaitkan dengan pengalaman yang dialami baik dari diri sendiri maupun orang lain.

\section{UCAPAN TERIMAKASIH}

Terimaksih diucapkan kepada semua pihak yang telah mendukung terselenggaranya kegiatan pengabdian masyarakat melalui webinar dengan segala keterbatasan disebabkan karena pandemi Covid-19.

\section{DAFTAR RUJUKAN}

Borich, G. . (1994). Observation Skill For Effective Teaching. Macmillan Publishing Company.
Goleman, D. (1999). Emosional Intelligence. PT. Gramedia Pustaka Utama.

Jannah, N. (2017). Pengaruh Zikir al-Ma'tsurat dan Terjemahannya Terhadap Penurunan Kecemasan Siswa Menghadapi Ujian Nasional. Jurnal Studia Insania, 5(2), 155. https://doi.org/10.18592/jsi.v5i2.1480

Joyce, B., \& Weil, M. (1980). Models of Teaching (Second Edition). PrenticeHall, Inc.

Raka, J. (1984). Pokok-Pokok Pikiran Mengenai Pendidikan Guru. Ditjen Dikti.

Sa, U., \& Ariati, J. (2018). Hubungan Antara Student Engagement (Keterlibatan Siswa) Dengan Prestasi Akademik Mata Pelajaran Matematika Pada Siswa Kelas Xi Sma Negeri 9 Semarang. Empati, 7(1), 69-75.

Sudiarta, I. N. (2016). Interaksi Guru Dan Siswa Yang Efektif Dapat Meningkatkan Motivasi Belajar Pada Siswa Smk Tkj 1Dwijendra Denpasar. Jurnal Kajian Pendidikan Widya Accarya FKIP Universitas Dwijendra, 6. https://doi.org/https://doi.org/10.46650/ wa.6.2.299.\%25p

Tynjälä, P., Virtanen, A., Klemola, U., Kostiainen, E., \& Rasku-Puttonen, H. (2016). Developing social competence and other generic skills in teacher education: applying the model of integrative pedagogy. European Journal of Teacher Education, 39(3), 368-387.

https://doi.org/10.1080/02619768.2016 .1171314

Vivin, V. (2019). Kecemasan dan motivasi belajar. Persona:Jurnal Psikologi Indonesia, 8(2), 240-257. https://doi.org/10.30996/persona.v8i2.2 276

Wu, Z., Hu, B. Y., Fan, X., Zhang, X., \& Zhang, J. (2018). The associations between social skills and teacher-child relationships: A longitudinal study among Chinese preschool children. Children and Youth Services Review, 88 , 582-590. https://doi.org/10.1016/j.childyouth.201 8.03.052 